\title{
Včera a dnes - Terézia Vansová v slovanskom literárnom kontexte
}

\author{
Eliška Gunišová (Brno)
}

\begin{abstract}
Abstrakt
Účelom predloženej práce je poskytnút verejnosti pohl'ad na slovenskú spisovatel'ku Teréziu Vansovú (1857 - 1942) z perspektívy, ktorá je vo vztáahu k nej doteraz skôr opomínaná, a teda predložit informácie o kontaktoch T. Vansovej mimo domáci kultúrny kontext a domácich adresátov jej tvorby (na ktorých sa sama autorka cielene zameriavala), t. j. analyzovat' jej zahraničný presah, a to najmä v slovanskom kultúrnom okruhu, ktorého si Vansová pod vplyvom myšlienok všeslovanskej vzájomnosti všímala najvýraznejšie. Neopomenutel'nou súčastou zahraničných kontaktov, ktorým bude venovaná pozornost', bude i ženské hnutie prúdiace strednou Európou v 19. storočí, ktoré bolo i výrazným mimoliterárnym vplyvom rezonujúcim dobovou spoločnostou a prirodzene reflektovaným T. Vansovou. Táto netradičná tematická perspektíva je vzhl'adom k nedostatku sekundárnych zdrojov postavená predovšetkým na primárnych, archívnych materiáloch - súčastou príspevku sú vybrané záznamy z osobnej korešpondencie, informácie o realizovaných i nerealizovaných prekladoch, ako i informácie súvisiace s Dennicou, prvým slovenským časopisom pre ženy, ktorého redaktorkou bola práve T. Vansová.
\end{abstract}

\section{Klúčové slová}

Terézia Vansová; Slovania; Dennica; slovanská vzájomnost'

\section{Abstract \\ Yesterday and Today - Terézia Vansová in the Slavic Literary Context}

The purpose of this work is to provide the reading public with the view on the Slovak writer Terézia Vansová (1857-1942) from the perspective that was in close relation to this author rather omitted till now, the information and the overview of Vansová's contacts out of domestic cultural context and domestic audience, what she deliberately focused on, hence to analyse her international overlap, especially to the Slavonic cultural environment that was subject to Vansová's interest under the contemporary idea of Slavonic reciprocity. An indispensable integral of international contacts a special attention will be paid to, is the women's movement circulating throughout 19th-century Central Europe ahoch represented a significant extra-literary influence resonating in the society of her time and naturally reflected by Vansová. Due to the lack of secondary sources this unconventional thematic perspective is based on primary, archival material - a part of the paper is represented by selected parts from personal correspondence, the information about the realized and unrealized translations as well as the information related to Dennica, the first Slovak magazine for women edited by Vansová.

\section{Keywords}

Terézia Vansová; the Slavs; Dennica; Slavonic reciprocity 
„Kým nebudeme cítit, že sme Slovania, nebudeme ani dobri Česi, ani dobri Slováci..."1

Vansová ako osobnost’ slovenských literárnych a kultúrnych dejín bola ${ }^{2}$ a stále i je ${ }^{3}$ intenzívne reflektovaná slovenskou odbornou verejnostou, avšak takmer výlučne v kontexte slovenského prostredia, kým analýze v mimoslovenskom kontexte doposial' unikala. Práve tento presah bude klúčový pre predloženú prácu, ktorej účelom bude venovat pozornost̉ reflektovaniu T. Vansovej v slovanskom, ale zároveň mimoslovenskom kontexte. Hoci platí repetitio mater studiorum, v tomto prípade by zmapovanie reflektovania Vansovej slovenskou odbornou verejnostou vyžadovalo priestor minimálne v rozsahu samostatného článku. Preto i ked' Vansovej literárne diela sú primárne určené pre slovenskú čitatel’skú verejnost’ a rovnako jej redaktorská a osvetová práca bola smerovaná pre Slovenky, my sa v tomto prípade zameriame na prípady, kedy sa Vansová vymyká z pomyselných hraníc slovenskej literatúry a dostáva sa aj do slovanského povedomia v širšom literárnom a kultúrnom kontexte.

Vansová sa o slovanský svet zaujímala, a nie iba okrajovo, čo nám ilustruje už úvodný citát. Avšak nielen Vansová, ale celá generácia slovenských spisovatelov 19. storočia bola vychovávaná v myšlienkach slovanskej afinity, ktorej rezíduá v slovenskom prostredí boli zvýraznené ideami Jána Kollára a Pavla Jozefa Šafárika, následne sa modifikovali v období romantizmu, až ich určitým spôsobom proklamoval i Svetozár Hurban Vajanský ako koryfej slovenského literárneho realizmu a predovšetkým aj vel'ký vzor T. Vansovej. Vajanský ale propaguje model slovanstva na čele s ruským národom (dokonca tvrdil, že ak by sa Slovania mali zjednotit', tak zjednocujúcim jazykom by mala byt ruština ${ }^{4}$ ), kým Vansová pocitovala najintenzívnejšiu príbuznost' Slovákov s národom českým.

Nielen geografická, ale najmä jazyková a kultúrna blízkost̉ slovenského a českého etnika spôsobila, že reflexia českej tvorby, ale i sociokultúrnych reálií bola obzvlášt u slovenských spisovateliek výrazná: „Naše milé sestry české prekvapily nás opät' novým dielom. Ony, neúnavné v práci na poli literatúry, neochabujúc v boji za urovnoprávnenia žien, neustávajú, ale idú krok za krokom d’alej ku vytknutému ciel’u. V otázke ženskej práci, ženského vzdelania vy-

1 VANSOVÁ, Terézia: [osobná korešpondencia]. [1926-3-31]. Dostupné v: LA SNK 150 I 8.

2 Z prác, ktoré v minulosti snád’ najvýraznejšie podporili všeobecné i odborné povedomie o Vansovej, je potrebné pripomenút minimálne: MRÁZ, Andrej: Literárne dielo Terézie Vansovej. Martin: Živena, 1937; VÁCLAVÍKOVÁ-MATULAYOVÁ, Margita: Život Terézie Vansovej. Bratislava: Slovenská liga, 1937; KOCÁK, Michal (ed.): Literárny archív 29 - 30. Terézia Vansová. Martin: Matica slovenská, 1994, s. 193 - 262.

3 Medzi najaktuálnejšie a najvýraznejšie práce reflektujúce Vansovej literárnu i osvetovú činnost’ v slovenskom kontexte patria určite práce: MIKULOVÁ, Marcela: Tri spisovatel'ky (Šoltésová, Vansová, Timrava). Bratislava: VEDA, 2015, časti ktorej môžeme nájsț už v skoršie vydaných zborníkoch, nielen v slovenskom jazyku, a monografia HOLLÝ, Karol: Ženská emancipácia. Bratislava: Historický ústav SAV, 2011. Frapantný význam majú v súčasnom diskurze aj práce vznikajúce pod hlavičkou slovenskej feministickej organizácie Aspekt, ktorá v roku 2011 vydala aj čítanku Vansovej menej známych diel Slovenka doma i na cestách.

4 Vyberáme z Vajanského korešpondencie uverejnenej v časopise Prúdy v článku Slovenské snahy o uvedenie ruštiny na Slovensku: „... som ešte o mnoho väčši horlitel’ za jednotu spisovného jazyka, jako Vy a Vaši súkmenovci. Len v tom sa delíme, že ja považujem za jediný možný jazyk, ktorý by nás sjednotil, jazyk ruský!“ Citované podla: BRONNEROVÁ, Šarlota: Svetozár Hurban Vajanský a Slovanstvo. Brno: Filozofická fakulta MU [státní práce], 1931, s. 40. Svoje argumenty o podobnosti slovenčiny a ruštiny neskôr publikoval v článku Ruština a slovenčina. Slovenské pohlady, 1885, č. 3. 
konaly tak mnoho, že nie len že nezaostaly, ale predčia ženský svet nejednoho vzdelaného štátu. " ${ }^{5}$ České prostredie predstavovalo celkovo pre Slovenky silnú inšpiráciu, a táto skutočnost' bola intenzívne citel'ná aj vo Vansovej umeleckej tvorbe - znalosṫ dobovej českej tvorby a reálií autorka jednak v mnohých prípadoch sama proklamovala (sú zachované záznamy o tom, že rada čítala predovšetkým V. K. Klicperu, B. Němcovú ${ }^{6}$, J. K. Tyla, J. Arbesa a V. Hálka), ale pretavovala ju i do svojich diel. Sama autorka sa verejne priznávala k neskonalému obdivu jednoduchého jazyka Němcovej Babičky ${ }^{7}$, ktorý jej slúžil ako vzor pre písanie vlastných kníh; mravné ideály, úcta k rodičom a nesebecká služba iným či schopnost' hlavnej hrdinky Sylvy z Vesnického románu Karolíny Světlej nájst̉ zmysel života v nezištnej práci, je podobná obetavej Viole z románu Sirota Podhradských. V neposlednom rade nesmieme zabudnút na ideálne vykreslenie českého prostredia vo Vansovej cestopise Pani Geogiadesová na cestách a pod.

Zvýšený záujem Terézie Vansovej o české prostredie a kultúru nebol založený výhradne na princípe národnostnej - slovanskej príbuznosti, ale významným elementom, špecifickým pre Vansovú ako ženskú autorku, bola vyspelosť českého ženského hnutia (časopisy, spolková činnost', školstvo a pod.) predstavujúca ideálny vzor pre Slovenky. Kým recepcia na linke české prostredie - Terézia Vansová je vo vel'kej miere zrejmá, preukázaná a ako taká len tažko spochybnitel'ná, recepcia opačným smerom predstavuje menej známu literárnohistorickú skutočnost́. Jeden z najintenzívnejších a najpodstatnejších kontaktov bol pre Vansovú český slovakofil Karel Kálal, na ktorého podnet vznikla Dennica - ženský list pre poučenie a zábavu ako prvý slovenský časopis pre ženy. ${ }^{8}$ A práve i vd’aka Dennici

5 VANSOVÁ, Terézia: [rukopis článku]. Dostupné v: LA SNK 198 AB 19.

6 Fascinácia Vansovej Boženou Němcovou zaujala literárnych vedcov už v minulosti, ale i dnes. Už v prvej monografii venovanej T. Vansovej (Literárne dielo Terézie Vansovej) Andrej Mráz uvádza, že obsiahlejšia komparácia života a tvorby T. Vansovej a B. Němcovej by bola iste podnetnou. L. N. Jégé sa v osobnej korešpondencii adresovanej Vansovej zmienil, že by mala napísat slovenskú Babičku. VANSOVÁ, Terézia: [osobná korešpondencia]. Nedatované. Dostupné v: LA SNK 198 X 16. Samostatnú štúdiu tomuto vztahu napokon venuje MIKULOVÁ, Marcela: Terézia Vansová, Božena Němcová a koncept neskorého biedermeieru. In: GÖRÖZDI, Judit - MAGOVÁ, Gabriela (eds.): Tvorivost́ literárnej recepcie. Bratislava: Veda, 2008, s. 42 - 47. Štúdiu je možné nájst’ i v MIKULOVÁ, Marcela: Vansovej neskorý biedermeier. In: MIKULOVÁ, Marcela - MIKULA, Valér (eds.): Kapitoly zo slovenského realizmu: Dejiny, medailóny, štúdie, interpretácie. Bratislava: Univerzita Komenského, 2010, s. 119 - 126. A napokon je táto štúdia zaradená i v jej najnovšej monografii MIKULOVÁ, Marcela: Tri spisovatel'ky (Šoltésová, Vansová, Timrava). Bratislava: Veda, 2015.

7 „Babička je v Čechách tou najpopulárnejšou a najviac čítanou knihou. Je priamo nesmrtelná, je stará a predsa vždy svieža a živá. Jej reč je taká jednoduchá a predsa obsažná, lebo podáva v l'ahúčkom rúchu nejednu životnú múdrost'. Pri čitani tejto knihy máme dojem, že je pisaná nie len neutuchajúcou láskou k predmetu a zvlášt’ $k$ postave drahej starenky, ale že nám tu podáva čast’ samej seba; čiastku svojej vrelocítiacej, za všetko krásné nadšenej duše, svojho vel'kého umu a nevšedného, samostatne súdiaceho ducha." VANSOVÁ, Terézia: Predmluva. In: NĚMCOVÁ, Božena: Babička. Zlatý fond denníka SME, 2013, [2016-10-4]. Dostupné na: http://zlatyfond.sme.sk/dielo/1830/Nemcova_Babicka.

8 Kálal pôvodne oslovil s myšlienkou vydávania Dennice E. M. Šoltésovú, tá návrh odmietla. Vansová ponuku redigovania časopisu prijala i napriek odmietavému postoju jej okolia: „Môj muž nesúhlasí so založením nového a sice ženského listu [...] Jedna zo spolupracovníc, na ktorú som sa opierala, tiež nesúhlasí. Je to Bella Textorisová. Marina Horváthová je znechutená [...]“. VANSOVÁ, Terézia: [osobná korešpondencia]. [1897-915]. Dostupné v: LA SNK 41 TTT 55. Viac o vývoji Dennice: GUNIŠOVÁ, Eliška: The Historical and Social Role of the First Slovak Women's Periodical „Dennica“. In: MCGREEVY, Michael - RITA, Robert (eds.): CER Comparative European Research 2015 - International Scientific Conference for Ph.D. students of EU countries. London: Sciemcee Publishing, 2015, s. 283 - 286. 
sa stali Vansovej kontakty nielen s českým, ale s celým slovanským svetom intenzívnejšie. Vansová ako redaktorka v snahe posilnit čitatel'skú základňu svojho časopisu a rozšírit počet predplatitel'ov, vd’aka ktorým by sa zvýšili príjmy a celkovo sa tak zlepšila situácia finančne nestabilného periodika, prejavovala ambície čiastočne preniknút s časopisom i do mimoslovenského sveta a práve tam získat nových predplatitelov periodika, ktorých príspevky by pomohli k lepšiemu finančnému zaisteniu časopisu.

Vansovej redaktorská práca preto neunikla pozornosti českých časopiseckých kruhov, tieto snahy vítali a podporovali predovšetkým propagovaním Dennice v českých periodikách. Podobnú pomoc ilustruje i skutočnost', že v čase zápasenia Vansovej s finančnými problémami pri vydávaní časopisu Slovenská žena (slovenského periodika pre ženy, ktoré redigovala v rokoch 1920 - 1923), dostala Vansová z českej redakcie Ženského obzoru ponuku, aby sa časopis Slovenská žena spojil so Ženským obzorom a bol vydávaný ako príloha tohto časopisu nad’alej redigovaná Teréziou Vansovou, avšak už bez tarchy finančného zaistenia jeho existencie a s výhodami redakčnej spolupráce: „Mimo toho Vám nabizime, že Vám při naši revui, poskytneme možnost vydávati Slovenskou ženu, jako přilohu našeho ,Ženského obzoru' kterou byste samostatně vyplňovala a nebo nám posílala materiál, který bychom za Vás, když nejste zdráva, spracovali."9

Je zrejmé, že Vansová nebola pre české prostredie neznámym pojmom, a preto ju, predovšetkým od začiatku 20. storočia, české spolky, redakcie a nakladatel'stvá oslovujú tentokrát ako autorku a prispievatel'ku. ${ }^{10}$ Osobná korešpondencia Terézie Vansovej uchovaná v Literárnom archíve Slovenskej národnej knižnice naviac dodnes dokladuje jej živú komunikáciu a čelnými predstavitel'kami českého ženského hnutia na témy literárne, ako i témy týkajúce sa ženského hnutia v dobovom Rakúsko-Uhorsku, respektíve neskôr v slovenskej časti novovzniknutej republiky. Okrem snáh nadviazat písomný kontakt s Eliškou Krásnohorskou sa dochovala i obsiahlejšia korešpondencia s redaktorkou českého ženského časopisu Ženský svět, Terezou Novákovou, ktorá vo svojich listoch chválila Dennicu a žiadala od Vansovej články týkajúce sa nielen situácie Sloveniek, ale i ženskej otázky na uhorskom území obecne, neopomínajúc pritom neslovanský okruh, menovite Mad'arky ${ }^{11}$ i Rumunky, s ktorými mala Vansová vel'mi dobré kontakty. Ohladom literárnych prác Vansová prijímala rady od českej publicistky Maryši Šáreckej Radoňovej. ${ }^{12}$ I osobne

9 Ženský obzor. [1923-12-28]. Dostupné v: LA SNK 41 JJ 7.

10 Napríklad pre plánované vydanie knihy nakladatelstva Veleslavín žiadali Vansovú o zaslanie humornej príhody do knihy Veselé př́hody ze života spisovatelů a umělců; v zborníku Od Šumavy k Tatrám venovanému podpore česko-slovenských vzţahov Vansová publikovala svoju novelu Hojže Bože; redakcia Žena a domov prosila Vansovú o spomienku z detstva, pretože chceli vydat slovenské číslo a počítali práve s príspevkami Sloveniek. Ženský obzor Vansovej poslal list: „Prosime Vás zároveň, byste nám občas zaslala nějakou zprávu do některých našich rubrik“. Redakcia Ženský obzor. [osobná korešpondencia]. [1923-12-28]. Dostupné v: LA SNK $41 \mathrm{JJ} 7$. Vansovej diela však nachádzame i v d'alších periodikách, vel’mi často uverejňovala práce v Českom lide, napr. Vajce v podani slovenského l’udu (1897), Z tej trinástej školy (1898), Paberky povier a obyčajov z Gem. Malohontu (1899), Detské povedačky, zpevy a hracky (1899).

11 NOVÁKOVÁ, Tereza: [osobná korešpondencia]. [1898-12-18]. Dostupné v: LA SNK 230 B 13.

12 ŠÁRECKÁ-RADOŇOVÁ, Maryša: [osobná korešpondencia]. [1927-12-23]. Dostupné v: LA SNK 198 Z 2. 
sa Vansová stretla s Vilmou Seidlovou-Sokolovou, ${ }^{13}$ Sokolová bola zároveň autorkou rubriky Slovenky - naše nejbližší sestry, ktorá bola pravidelne uverejňovaná v časopise Ženský svět a Sokolová v nej informovala o aktivitách Sloveniek, pričom sa stala i platformou pre prezentovanie Vansovej literárnych prác českým čitatel'kám.

Vansovej významnú úlohu a prínos v (česko)slovenskom a ženskom snažení, ako aj ich recepciu doma s v zahraničí dokladujú archívne dokumenty z rokov po vzniku ČSR, kedy Vansová oslavovala svoje okrúhle jubileá. Jej 70. a 80. narodeniny v roku 1927 a 1937 sa stali vhodnou a využívanou príležitostou k ich pripomenutiu prostredníctvom jej biografických medailónikov, ${ }^{14}$ ale i cenných rozhovorov s autorkou, ${ }^{15}$ ktoré pri týchto príležitostiach poskytla periodickej tlači a v ktorých odhalila mnoho zo svojho života. Vansová, v tomto období už ako známa spisovatel'ka a významná propagátorka česko-slovenskej vzájomnosti, prijímala pri tejto príležitosti množstvo gratulácií, ktoré sú síce obsahovo nezaujímavé, avšak dokladujú jej ohlas u osobností domáceho ${ }^{16}$ i zahraničného prostredia. ${ }^{17} \mathrm{Z}$ dochovaných listov sa ale môžeme dozvediet aj to, že ženské spolky združujúce prevažne Češky a Slovenky v zahraničí (a to napríklad v Amerike alebo v dnešnom Srbsku, či Rumunsku) využili tohto výročia na usporiadanie verejných prednášok venovaných práve osobnosti T. Vansovej, jej literárnej tvorbe, ako i jej kultúrno-osvetovým aktivitám. ${ }^{18}$

$\mathrm{S}$ českým prostredím nesúvisia iba osobné a korešpondenčné kontakty či inšpirácia v tvorbe a kultúrnej činnosti. Neopomenutelnou súčastou predloženej problematiky sú i preklady literárnych diel. Napriek skutočnosti, že Vansovej práce boli v českom prostredí publikované predovšetkým v slovenskom jazyku (existuje iba jeden kompletný preklad do češtiny, a to konkrétne románu Sirota Podhradských - Viola Podhradská. Román dívky z roku 1972), ${ }^{19}$ zaujat’ by nás mohli predovšetkým Vansovej preklady českých diel do slovenčiny. Najznámejší z nich je preklad diela B. Němcovej Babička, ${ }^{20}$ ktorý v roku 1927

13 Vilma Sokolová-Seidlová o Vansovej píše: „... roztomilá Tereza Vansová [...] plna vlídné ochoty ke mně...". SOKOLOVÁ-SEIDLOVÁ, Vilma: Z mých vzpominek na Slovensko. Slovenské pohlady 45, 1929, č. 8, s. 477.

14 Napr.: U Terezy Vansové. Lidové noviny 45, 1937, č. 193, s. 6; Terezie Vansová osmdesatiletá. Lidové noviny 45, 1937, č. 196, s. 16; Jubileum zasloužilé pracovnice pro uvědoměni slovenských žen. Národní listy 67, 1927, č. 91, s. 1; VESELÝ, Adolf: Jubileum Terezie Vansové. Národní listy 77, 1937, č. 107, s. 15.

15 Napr.: SÁLKA, Viliam: Zo spomienok Terezie Vansovej. Lidové noviny 42, 1934, č. 196, s. 3.

16 Medzi gratulantov patril okrem iných i predseda vlády Milan Hodža.

17 Dochované sú predovšetkým oficiálne gratulácie od zahraničných spolkov, s ktorými Vansová spolupracovala, v menšej miere aj gratulácie jednotlivcov zo zahraničia.

18 Ako príklad môžeme uviest̉ dochovanú informáciu o návšteve dvanástich žien z brnianskej Vesny (ktorej bola Vansová niekol'ko rokov oficiálnou spolupracovníčkou) v Banskej Bystrici práve pri príležitosti Vansovej životného jubilea. Návšteva sa odohrala 12. 5. 1937. Archívny fond T. Vansovej [výstrižok z novín]. Dostupné v LA SNK 41 PPP. Spolek slovanských žen v Olomouci zorganizoval 21. 6. 1937 pri príležitosti Vansovej jubilea prednášku o jej živote a diele. Spolek slovanských žen v Olomouci. [osobná korešpondencia]. Dostupné v: LA SNK 41 DD 16. V Petrovci miestny odbor Sdružení československých žen v Juhoslávii usporiadal oslavy pri príležitosti Vansovej 80. narodenín. Pozri: Archívny fond T. Vansovej. [výstrižok]. Dostupné v: LA SNK 41 RRR.

19 VANSOVÁ, Terézia: Viola Podhradská: román dívky. Bratislava: Mladé letá, 1972. Prekladatelom do češtiny bol Jindřich Hilčr.

20 „Kde len bolo možno, šetrila som pôvodinu, aby prišla $k$ nám taká milá a vzácna, ako ju pred 70 rokami jej slávna autorka vypravila. - Usilovala som sa, nie len aby som zachovala takrečený odkaz duše najväčšj spisovatel'ky, ale keby bolo možné, vložila by som i môj neohraničený obdiv a lásku k jej dielu do toho, lebo je Božena Němcová mojím 
potvrdila vydavatel'stvu Slovenský východ, aj ked's vydávaním podobných prekladov osobne nesúhlasila ${ }^{21}$ : „Nemyslela som, žeby som dakedy mala prekladat’ z českej reči do slovenskej. Vždy som bola toho názoru a myslím, že by malo byt', aby sa slovenské knihy čitaly v Čechách tiež v pôvodnom jazyku. "22 Následne od Němcovej preložila ešte dve prózy - Pohorská dedina (1928) a Pán učitel' (1930) a pre rovnaké vydavatel'stvo súhlasila aj s prekladom diela Filosofská historie od A. Jiráska. ${ }^{23}$

S prekladmi možno spojit’ aj Vansovej kontakty s južnoslovanským prostredím. Práve o preklad Vansovej prvého románu (Sirota Podhradských) do chorvátskeho jazyka prejavila vážny záujem Anna Šišuliaková: „Osmelujem sa Vás úctive prosit’ o dovolenie Váš výborný román ,Sirota Podhradských“ smiet’ preložit’ do horvačtiny, za našu Maticu Hrtvatsku. "24 Hoc sa opätovne jedná pravdepodobne o nezrealizovaný projekt, pre nás je podstatná i pôvodná intencia. Rovnako sa z archívnych materiálov môžeme dozvediet, že tento Vansovej román vychádzal v slovenskom jazyku v prílohe časopisu Hlas ludu v Petrovci, a teda v centre slovenskej diaspóry v dnešnom Srbsku.

$\mathrm{S}$ južnoslovanským prostredím súvisí i Vansovej cestopis - Z rovín dolnozemských. ${ }^{25} \mathrm{Ne}-$ možno tvrdit, že sa jedná o zásadné dielo vo Vansovej tvorivom profile, nie je jedinečné svojou poetikou a nebolo dokonca ani knižne vydané (čitatel'ky si ho mohli prečítat iba na stránkach Dennice). Napriek tomu predložený cestopis poukazuje na dve nezanedbatel'né skutočnosti: Vansová mala osobné kontakty s južnými Slovanmi a sama sa ako redaktorka v rámci nenáročnej formy zábavného čítania snažila svojim recipientom (recipientkám) ponúknut relatívne fundovaný faktografický náčrt zo života južných Slovanov.

Názorným príkladom tohto redaktorského zámeru realizovaného nielen v južnoslovanskom areáli je korešpondencia s Albertom Škarvanom - významným propagátorom Tolstého myšlienok na slovenskom území. Vansová vedela o jeho dočasnom pobyte v Rusku, a preto, hoc nemala osobné kontakty na Rusko, snažila sa aspoň sprostredkovane poskytnút slovenskej čitatel'skej obci informácie o ruských ženách („Ked’ som redigovala Dennicu, chcela som vediet’ niečo o ruskej žene. Rusko, ako sa všeobecne vie, sme zbožňovali. “26). To, že táto epizóda končí neúspešne, je už paradox. Škarvan ponuku vel’mi rád prijal ${ }^{27}$ a poslal Vansovej nielen svoje názory na ruské ženy, ale dokonca získal niekol'ko písom-

ideálom. Je to jedinečné dielo slávnej spisovatelky. " VANSOVÁ, Terézia: Predmluva. In: NĚMCOVÁ, Božena: Babicka. Zlatý fond denníka SME. [cit. 4. 10. 2016]. Dostupné na: http://zlatyfond.sme.sk/dielo/1830/ Nemcova_Babicka.

21 Súhlas Vansovej s prekladmi českých diel do slovenčiny je nutné odôvodnit výraznými finančnými problémami, ktoré mala Vansová predovšetkým v dvadsiatych rokoch 20. storočia.

22 VANSOVÁ, Terézia: [osobná korešpondencia]. [1927-9-21]. Dostupné v: LA SNK 41 CC 33.

23 Pî̃e sa o tom v liste: VANSOVÁ, Terézia: [osobná korešpondencia]. [1927-9-21]. Dostupné v: LA SNK 41 CC 33. Napriek tomu tento preklad nie je dnes dohladatelný v knižniciach, a preto je možné sa nazdávat', že napokon nevyšiel.

24 ŠIŠULIAKOVÁ, Anna: [osobná korešpondencia]. [1912-7-8]. Dostupné v: LA SNK 41 EE 28.

25 VANSOVÁ, Terézia: $Z$ rovín dolnozemských. Dennica 9, 1907, s. 156 - 159, 183 - 186, 228 - 230, 288 - 291, $352-355,396-400$.

26 VANSOVÁ, Terézia: [osobná korešpondencia]. Nedatované. Dostupné v: LA SNK 230 B 21.

27 Zaujímavostou je, že Škarvana zaujala i Dennica a chcel do nej posielat ruské preklady. Pozri: ŠKARVAN, Albert: [osobná korešpondencia]. [1908-02-24]. Dostupné v: LA SNK 198 Z 4. 
ných vyjadrení aj od d’alších slovenských a českých rusofilov, avšak názory na ruské ženy boli natol'ko hanlivé, že Vansová - ako podporovatel'ka slovanskej vzájomnosti - sa rozhodla tieto názory vôbec neuverejnit. ${ }^{28}$

$\mathrm{S}$ prostredím ruského záboru na území dnešného Pol’ska súvisí ešte jedna doteraz nepublikovaná ${ }^{9}$ skutočnost', a to tá, že Jozef Škultéty, vtedajší šéfredaktor Slovenských pohladov, sprostredkoval Vansovej jediný preklad do ruštiny: „Ja posielam Vám novoročný dar: v prílohe Varšavského dnevnika preklad Vašej vianočnej povesti. "30 Vansová s vd’akou odpísala: „Ani ste ma nemohli prijemnejšie prekvapit, ako s týmto prekladom, ktorý si už aj sama prečitam, lebo som sa už naučila čitat’ po rusky. "

Kontakt s pol'ským kultúrnym prostredím však bol Vansovej sprostredkovaný predovšetkým prostredníctvom Dennice, a to konkrétne zo strany pol’skej ženskej čitatel'skej obce. $\mathrm{V}$ archívnych materiáloch totiž nachádzame záznamy o záujme na predplatenie Dennice čitatel'kami z Krakova a Varšavy. ${ }^{32}$ Vansová, napriek tomu, že Poliaci nestáli v popredí jej osobných záujmov, považovala priam za svoju povinnost̉ sa o pol’ské prostredie zaujímał’ z perspektívy panslavizmu i otázky ženskej emancipácie ako redaktorka. A preto, hoc nepravidelne, informovala o pol'skej kultúre v Dennici, ${ }^{33}$ pričom sama vyvíjala iniciatívu k samovzdelávaniu v tejto oblasti, aby mohla tieto informácie predkladat’ d’alej. Opätovne, ako pri iných slovanských krajinách, i v tomto prípade Vansová propagovala aj pol'ské literárne práce: „Minulého roku zasvätil vd'ačný národ pol’ský s nadšením a okázalostou medzi inými dvojaké jubileum: jubileum 40 ročnej literárnej činnosti slovńtnej spisovatel'ky pol'skej Elizy Orzeszkowej a jubileum šest'desiatročných narodenim a spolu i tridsatročnej literárnej činnosti Marye Konopnickej. Nám sú obe tieto mená už nie neznáme, ved' i Dennica viackrát priniesla niekol'ko krásných básni Marye Konopnickej vo vernom preklade nášho Horala a povesti Orzeszkowej v preklade Horina. "34

K dodnes dohladatel'ným informáciám o snahe prekladu Vansovej diela do d’alšieho slovanského jazyka a zároveň posledným výraznejším kontaktom Vansovej s pol’ským prostredím patrí nasledujúci úryvok: „Radujem sa z toho, že sa o Kliatbu zaujímajú v Polsku

28 „My Slováci sme si zuykli predstavovat’ Rusa č človeka nám obzvlášte blizkeho. To je omyl. Ruská povaha nám je d’aleká a cudzá a ruský život tiež. Naše rusofilstvo sa zakladá na úplnom neznani Ruska, keby sme znali Rusov, by naša zalúbenost’ do nich prestala [...] Ruska je nanajvýš špatná gazdiná [...] Domácnost' je im tarcha, nutné zlo [...] Ruska je márnotratná. Z mála moc urobit', hynúce reštaurovat', tak rečeno z ničoho pomaly a po troche prítulný kút zariadit', o tom všetkom sa Ruske ani nesníva [...] Ruska nezapláta, nezamrežká odev, ked' je tomu čas, a nosí svoju sukňu, nereparovanú, flakatú, smradl'avú do tých čias, pokial' si novú nekúpi. “ŠKARVAN, Albert: [osobná korešpondencia]. [1908-2-24]. Dostupné v: LA SNK 198 Z 4.

29 Nepublikovaná chápeme v zmysle, že daná informácia sa nenachádza v záznamoch SNK o publikovaných dielach T. Vansovej doma a v zahraničí. Informáciu je však možné nájsț v jednom z listov adresovaných T. Vansovej v publikovanej osobnej korešpondencii Jozefa Škultétyho. Jedná sa o Vansovej prozaické dielo Št’astná žena, ktorú uverejnila v Národných novinách v roku 1889. V ruskom preklade bolo publikované pod názvom Ščastlivaja ženščina (perevod so slovackogo). Pozri poznámka nižšie.

30 KOCÁK, Michal (ed.): Listy Jozefa Škultétyho 1. Martin: Matica slovenská, 1982, s. 57.

31 VANSOVÁ, Terézia: [osobná korešpondencia]. [1890-1-13]. Dostupné v: LA SNK 49 EE 31.

32 RENDEK, Ján: [osobná korešpondencia]. [1899-11-12]. Dostupné v: LA SNK 41 AA 19.

33 VANSOVÁ, Terézia: Marya Konopnická. O literárnej tvorbe na jej 25. ročné spisovatelské jubileum. Dennica 5, 1902, č. 11, s. $234-237$.

34 VANSOVÁ, Terézia: Jubileum dvoch spisovateliek (Orzeskowska a Konopnicka). Dennica 10, 1907, č. 1, s. 27. 
a verim, že kniha v polskej reči výjde. Odpisal som sám na pána prof. Pazurkiewicza a poslal som mu brožovaný výtisk Kliatby a okrem toho písal menovanému profesorovi tunajší polský konzulát, ktorý vrele odporúčal preložit' Kliatbu do polskej reči. Profesora Pazurkiewicza som žiadal, aby stanovil honorár a som presvedčený, že, ak bude knihu prekládat', bude honorár dobrý. "35 Snaha Jána Grünwalda, redaktora vydavatel'stva Slovenský východ, ktoré vydalo niekol'ko Vansovej kníh, však zostala pravdepodobne opätovne nenaplnená - o polskej verzii Kliatby sa dnes nedarí nájsţ žiadne informácie.

Predložené archívne záznamy o snahe spolupracovat’ s inými národmi nie sú obmedzené iba na slovanské krajiny, výrazné kontakty má Vansová napríklad s Rumunkami a Slovenkami žijúcimi v tejto oblasti: „Dôležitá úloha sprostredkovatel’a medzi rumunskými a slovenskými sestrami - tak sa vzájomne v dopisoch oslovovaly - pripadla skromnému redaktorovi vtedajšej Tribuny Augustinimu. On nielen vyučoval mladé Rumunky slovenčine - slečna Agnes Cristea za jeho vedenia prekladala Vansovej novelu zo Slovenských pohladov - ale aj povzbudzoval, urgoval a vyjednával na obidvoch stranách. Dokázal sa vtedy spolu s Teréziou Vansovou skvelým organizátorom ako aj hbitým, nadšeným propagátorom. Jeho meno vedl'a mena našej vynikajúcej spisovatel'ky nesmie veru nikdy vymiznút' z bohatých análov slovensko-rumunského sbliženia. " ${ }^{36}$ Vansová bola medzi Rumunkami známa nie iba ako už etablovaná spisovatel'ka, ale poznali ju od počiatkov jej tvorby, a to vd’aka kontaktom, ktoré nadviazala prostredníctvom svojich aktivít na podporu Vajanského počas jeho pobytu vo väzení za propagáciu protimad’arských myšlienok. Rovnako ilustratívna môže byt' i informácia, že i tieto ženy boli predplatitel'kami Dennice a následne aj Slovenskej ženy.

Vansová sa ako spisovatel'ka snažila prerazit’ tiež na mad’arský knižný trh. Už v roku 1890 zistovala možnosti preloženia Siroty Podhradských do mad’arčiny, dostala však odpoved’ ilustrujúcu tažkú dobovú situáciu slovenského autora s obdobnými ambíciami: „Pred slovenskou knižkou všetci redaktori krčia nosom. " ${ }^{37}$ A jediný knižný preklad do mad’arčiny je napokon Julinkin prvý bál (Juliska elsö bálja) z roku $1966 .{ }^{38}$ Ešte v začiatkoch svojej tvorby posielala svoje diela aj do slovenských periodík v Amerike, ale rovnako nechávala priestor pre krajanky z Ameriky v Dennici. ${ }^{39}$ A to sú len vybrané ilustračné príklady mimoslovanských kontaktov.

Z uvedených informácií je zrejmé, že naplnenie programu Terézie Vansovej na poli posilnenia slovanskej vzájomnosti i všeobecnej ženskej emancipácie nebolo len prázd-

35 GRÜNWALD, Ján: [osobná korešpondencia]. [1928-3-2]. Dostupné v: LA SNK 41 CC 33.

36 HUŠKOVÁ-FLAJŠHANSOVÁ, Jindra: Cenná politická epizóda zo života Vansovej. [výstrižok z novín]. Nedatované. Dostupné v: LA SNK 41 RRR.

37 CZAMBEL, František: [1890-11-1]. [osobná korešpondencia]. Nedatované. Dostupné v: LA SNK 41 D 31.

38 VANSOVÁ, Terézia: Juliska elsö bálja. Bratislava: Mladé letá, 1966. Autorom prekladu do mad’arčiny je István Käfer. Vansovej tvorba bola ešte predtým súčastou krátkej antológie slovenských autorov vydanej v mad'arčine. FARKAS, Zoltán (ed.): Szlovák prózai antológia : (a szlovák prózai antológiát a szlovák-magyar irodalmi barátság kimélyítésére, utat mutatandó az eljövendö generációnak, hogyan lehet a megértés útját egyengetni.). Šahy: Ipolyság, 1928.

39 „V časopise Dennica, redigovanom Teréziou Vansovou, uverejňovali členky Živeny v USA správy o činnosti [...] posielali články zo života slovenských žien v Amerike a ziskavali predplatitelky pre časopis z radov krajaniek." BARTALOVÁ, Lubica: Americká Živena a jej kontakty so Živenou na Slovensku. In: SEDLÁKOVÁ, Viera (ed.): Zborník z osláv 125. výročia Živeny spolku slovenských žien v Martine. Martin: Živena, 1995, s. 140. 
nou proklamáciou, ale i jej reálnou snahou a túžbou, a to predovšetkým na prelome 19. a 20. storočia, kedy možno i vo Vansovej osobných vyjadreniach nájsț výraznú tvorivú odvahu a odhodlanie. Aktivity, ktoré Vansová podniká v dvadsiatych rokoch 20. storočia (najmä vydávanie nových diel a zároveň i preklady) súvisia skôr s finančnými tažkostami, ktoré Vansová v danom období mala ${ }^{40}$, „Ja musím pisat', lebo sme s mojou chovanicou fin. upadly." ${ }^{11}$

Predložený príspevok samozrejme nemôže obsahovo a zdrojovo vyčerpat zvolenú tému, avšak predstavený výber zdrojov zahrňujúcich najmä primárne archívne pramene a ich spracovanie dokazujú šírku, intenzitu i charakter vztahu Vansová - mimoslovenské prostredie, čo môže byt pre mnohých, oboznámených s obvyklým hodnotením autorkinho prínosu slovenskej literatúre, pomerne prekvapujúca informácia. Je nutné uznat', že Vansová je častokrát označovaná iba ako autorka triviálnej ženskej prózy, ${ }^{42}$ čo však profilovo nevypovedá o žene, ktorej sa v nel'ahkých sociálnych podmienkach najmä rakúsko-uhorskej spoločnosti podarilo svojou horlivostou a oddanostou k práci vytvorit so svetom pomerne značné väzby. Po spisovatel'kinej smrti (1942), i v súvislosti so sociálnymi a politickým zmenami a vzhladom na viaceré zamýšlané, no nezrealizované preklady, ktoré by jej literárny impakt a hodnotenie nepochybne zvýraznili, sa zmienky o Vansovej ako osobnosti i spisovatel'ke mimo slovenské územie obmedzili iba na niekol'ko záznamov v slovníkoch o významných ženách 19 . storočia, ${ }^{43} \mathrm{v}$ ktorých Vansová častokrát nefiguruje ani ako spisovatel'ka, ale predovšetkým ako zakladatel'ka časopisu Dennica, a len výnimočne môžeme nájsţ práce, ktoré sa už podrobnejšie venujú slovenským spisovatelkám vrátane samotnej Vansovej. ${ }^{44} \mathrm{~S}$ novoobnoveným záujmom o feminizmus či vznikom vedeckých a študijných odborov zaujímajúcich sa o tzv. gender studies sa Vansová dostala znovu do pozornosti aj v slovanskom okruhu. Je nutné pripomenút predovšetkým niekol'ko mien - Marcin Filipowicz, pol’ský bohemista pracujúci v Českej republike, ktorý Vansovej venoval niekol'ko štúdií, ${ }^{45}$ v ktorých sa snaží nanovo interpretovat poetiku vy-

40 Toto životné obdobie Vansovej zachycuje napríklad: ŠUCHOVÁ, Xénia: Smutný príbeh zo smutných čias: dve vojny v rodinnom živote Terézie Vansovej. Forum Historiae 3, 2009, č. 1. [online]. Dostupné na: http:// www.forumhistoriae.sk/documents/10180/39170/suchova.pdf. Viac sa však môžeme dozvediet aj priamo z dochovanej korešpondencie T. Vansovej, v ktorej píše, že mala „také dlhy, že na 3 - 4 domy by na ich vyplatenie nestačili“. VANSOVÁ, Terézia: [osobná korešpondencia]. Dostupné v: LA SNK: 198 AB 4.

41 VANSOVÁ, Terézia: [osobná korešpondencia]. [1926-3-31]. Dostupné v: LA SNK 150 I 8.

42 „Ja som svoje diela určila pre l’ud. Preto mi vel'mi zle padla kritika Bujnáka, ktorý všetky moje diela shrnul pod jeden, vraj charakteristický názov ,limonáda". SÁLKA, Viliam: Zo spomienok Terezie Vansovej. Lidové noviny 42, 1934, č. 196 , s. 3.

43 Napríklad: DE HAAN, Francisca - DASKALOVA, Krassimira - LOUTFI, Anna (eds.): Biographical Dictionary of Women's Movements and Feminisms in Central, Eastern, and South Eastern Europe, 19th and 20th Centuries. Budapest - New York: CEU, 2006.

44 Napríklad WEBER, Nora: Feminism, Patriarchy, Nationalism, and Women in Fin-De-Siecle Slovakia. Nationalities Papers, vol. 25, 1997, n. 1, s. 35-65, alebo RUDINSKA, Norma L.: Incipient Feminists: Women Wrilers in the Slovak National Revival. Columbus: Slavia Publishers, 1991 či novšie články ako SOULAS de RUSSEL, Dominique J. M.: L'imagologie, étude des stéréotypes nationaux, à l'exemple de ceux des Allemands dans la littérature slovaque de 1780 à 1914. Expressions, 2016, č. 2.

45 Vansovej cestopis rozoberá napríklad v štúdii: Pani Georgiadesová na cestách. Veselý cestopis do Prahy Terézie Vansové. Ženská verze ideologického cestopisu. Románu Sirota Podhradských sa venuje v knihe: Roditelky národů: z problematiky české a slovenské ženské literárni tvorby 2. poloviny 19. století (2007). 
braných Vansovej diel. Pozornost' Vansovej dielam venuje aj Maša Zavrtanik napríklad vo svojich slovinských prácach Semiotizacija potopisa Terézie Vansove ${ }^{46}$ alebo Fakti v literarnih delih Terezie Vansove kot vir pri spoznavanju načina življenja ljudi ${ }^{47}$.

Neupierajúc Vansovej jej zásluhy na poli literárnej tvorby, je zo širšej perspektívy mimoslovenského kontextu nutné každopádne dospiet’ k triezvemu a objektívnemu hodnoteniu jej recepcie a významu, ktorý môže byt tažko hodnotený ako výrazný v porovnaní s inými slovenskými osobnostami jej obdobia. Táto skutočnost̉ má však v kontexte Vansovej literárneho snaženia svoje ratio v jej špecificky determinovaných umeleckých ambíciách a cieloch, ktoré svojim dielam pripisovala - pre Vansovú bola vždy prvotná slovenská, často málo vzdelaná čitatel'ka, a práve jej Vansová prispôsobovala svoje diela samotnou poetikou či tematickým zameraním - takáto špecifická literatúra však len tažko mala šancu nájsţ širší ohlas v mimoslovenskom kultúrnom okruhu okrem tých najbližších. Iným vysvetlením môžu byt’ i obmedzené možnosti autorky, ktorá sa zväčša pohybovala mimo centrá slovenskej kultúry a úplne sa nevzdala ani svojich rodinných úloh.

Medzinárodne príliš nepoznaná Terézia Vansová sa zaradila k mnohých d’alším slovenským autorkám tvoriacim a pôsobiacim v rámci publikačnej, editorskej, spolkovej či edukačnej činnosti pre svoje čitatel'ky, členky a podporovatel'ky, prinášajúc tak moderný spoločenský trend hladania úlohy žien do slovenskej spoločnosti. Hoci daná cesta bola dlhá a náročná, práve vd’aka týmto ženám - ako bola v danej dobe Vansová - bolo možné budovat základy vzdelávania žien postavené i na uspokojení čitatel’ského dopytu slovenskej ženy. Faktom, ktorý je potrebné zdôraznit, je to, že Vansová ako osobnost’ poskytla tomuto ciel'u všestranný multidimenzionálny prínos často podporený jej osobnostnou charakteristikou - vytrvalostou a nevšednou odvahou naplnit’ svoje vytýčené zámery.

\section{Literatúra}

Archívny fond T. Vansovej. [výstrižok z novín]. Dostupné v LA SNK 41 PPP.

Archívny fond T. Vansovej. [výstrižok z novín]. Dostupné v: LA SNK 41 RRR.

BARTALOVÁ, Lubica: Americká Živena a jej kontakty so Živenou na Slovensku. In: SEDLÁKOVÁ, Viera (ed.): Zbornik z osláv 125. výročia Živeny spolku slovenských žien v Martine. Martin: Živena, 1995. BRONNEROVÁ, Šarlota: Svetozár Hurban Vajanský a Slovanstvo. Brno: Filozofická fakulta MU [státní práce], 1931.

CZAMBEL, František: [osobná korešpondencia]. [1890-11-1]. Dostupné v: LA SNK 41 D 31.

DE HAAN, Francisca - DASKALOVA, Krassimira - LOUTFI, Anna (eds): Biographical Dictionary of Women's Movements and Feminisms in Central, Eastern, and South Eastern Europe, 19th and 20th Centuries. Budapest - New York: CEU, 2006.

46 ZAVRTANIK, Maša: Semiotizacija potopisa Terézie Vansove. In: URKOM, Aleksander (ed.): Fiatal Szlavisták Budapesti Nemzetközi Konferenciája I. Budapest: Eötvös Loránd Tudományegyetem, 2012, s. 120 - 122.

47 ZAVRTANIK, Maša: Fakti v literarnih delih Terezie Vansove kot vir pri spoznavanju načina življenja ljudi. Sofia: Nacionalni slavistični četenija, 2010, s. 577 - 582. 
FARKAS, Zoltán (ed.): Szlovák prózai antológia : (a szlovák prózai antológiát a szlovák-magyar irodalmi barátság kimélyitésére, utat mutatandó az eljövendö generációnak, hogyan lehet a megértés útját egyengetni.). Šahy: Ipolyság, 1928.

FILIPOWICZ, Marcin: Pani Georgiadesová na cestách. Veselý cestopis do Prahy Terézie Vansové. Ženská verze ideologického cestopisu. In: Mezi deklamovánkou a románem. Proměny žánrů v české a slovenské literatuře. Praha: Ústav pro českou literaturu AV ČR, 2006, s. 97 - 106. [online]. [cit. 06.05.2015]. Dostupné na: http://www.ucl.cas.cz/slk/data/2005/sbornik/sbornik.pdf.

FILIPOWICZ, Marcin: Roditelky národi̊: z problematiky české a slovenské ženské literární tvorby 2. poloviny 19. století. Hradec Králové: Gaudeamus, 2007.

GRÜNWALD, Ján: [osobná korešpondencia]. [1928-3-2]. Dostupné v: LA SNK 41 CC 33.

GUNIŠOVÁ, Eliška: The Historical and Social Role of the First Slovak Women's Periodical „Dennica“. In: MCGREEVY, Michael - RITA, Robert (eds.): CER Comparative European Research 2015 - International Scientific Conference for Ph.D. students of EU countries. London: Sciemcee Publishing, 2015, s. 283 - 286.

HOLLÝ, Karol: Ženská emancipácia. Bratislava: Historický ústav SAV, 2011.

HUŠKOVÁ-FLAJŠHANSOVÁ, Jindra: Cenná politická epizóda zo života Vansovej. [výstrižok z novín]. Nedatované. Dostupné v: LA SNK 41 RRR.

KOCÁK, Michal (ed.): Listy Jozefa Škultétyho 1. Martin: Matica slovenská, 1982.

KOCÁK, Michal (ed.): Terézia Vansová. In: Literárny archív 29 - 30. Martin: Matica slovenská, 1994, s 193 - 262.

Jubileum zasloužilé pracovnice pro uvědoměni slovenských žen. Národní listy 67, 1927, č. 91, s. 1.

MIKULOVÁ, Marcela: Terézia Vansová, Božena Němcová a koncept neskorého biedermeieru. In: GÖRÖZDI, Judit - MAGOVÁ, Gabriela (eds.): Tvorivost́ literárnej recepcie. Bratislava: Veda, 2008, s. $42-47$.

MIKULOVÁ, Marcela: Tri spisovatelkyy (Šoltésová, Vansová, Timrava). Bratislava: Veda, 2015.

MIKULOVÁ, Marcela: Vansovej neskorý biedermeier. In: MIKULOVÁ, Marcela - MIKULA, Valér (eds.): Kapitoly zo slovenského realizmu: Dejiny, medailóny, štúdie, interpretácie. Bratislava: Univerzita Komenského, 2010, s. 119 - 126.

MRÁZ, Andrej: Literárne dielo Terézie Vansovej. Martin: Živena, 1937.

NOVÁKOVÁ, Tereza: [osobná korešpondencia]. [1898-12-18]. Dostupné v: LA SNK 230 B 13.

RENDEK, Ján: [osobná korešpondencia]. [1899-11-12]. Dostupné v: LA SNK 41 AA 19.

RUDINSKY, Norma L.: Incipient Feminists: Women Writers in the Slovak National Revival. Colombus: Slavica Publishers, 1991.

SÁLKA, Viliam: Zo spomienok Terezie Vansovej. Lidové noviny 42, 1934, č. 196, s. 3.

SOKOLOVÁ-SEIDLOVÁ, Vilma: Z mých vzpominek na Slovensko. Slovenské pohlady 45, 1929, č. 6 -8 , s. $453-483$.

SOULAS de RUSSEL, Dominique J. M.: L'imagologie, étude des stéréotypes nationaux, à l'exemple de ceux des Allemands dans la littérature slovaque de 1780 à 1914. Expressions, č. 2. 2016. [online]. [cit. 19.03.2017]. Dostupné na: http://fac.umc.edu.dz/fll/images/expressions/Dominique-J-M-SOULAS-de-RUSSEL.pdf

Spolek slovanských žen v Olomouci. [osobná korešpondencia]. Dostupné v: LA SNK 41 DD 16. SVĚTLÁ, Karolina: Vesnický román. Praha: Matice lidu, 1869. 
ŠÁRECKÁ-RADOŇOVÁ, Maryša: [osobná korešpondencia]. [1927-12-23]. Dostupné v: LA SNK $198 \mathrm{Z} 2$.

ŠIŠULIAKOVÁ, Anna: [osobná korešpondencia]. [1912-7-8]. Dostupné v: LA SNK 41 EE 28.

ŠKARVAN, Albert: [osobná korešpondencia]. [1908-2-24]. Dostupné v: LA SNK 198 Z 4.

ŠUCHOVÁ, Xénia: Smutný pribeh zo smutných čias: dve vojny v rodinnom živote Terézie Vansovej. Forum Historiae 3, 2009, č. 1. [online]. Dostupné na: http://www.forumhistoriae.sk/documents/10180/39170/suchova.pdf.

Terezie Vansová osmdesatiletá. Lidové noviny 45, 1937, č. 196, s. 16.

U Terezy Vansové. Lidové noviny 45, 1937, č. 193, s. 6.

VÁCLAVÍKOVÁ-MATULAYOVÁ, Margita: Život Terézie Vansovej. Bratislava: Slovenská liga, 1937.

VAJANSKÝ, S. H.: Ruština a slovenčina. Slovenské pohlady, 1885, č. 3.

VANSOVÁ, Terézia: Jubileum dvoch spisovateliek (Orzeskowska a Konopnicka). Dennica 10, 1907, č. 1, s. $27-29$.

VANSOVÁ, Terézia: Juliska elsö bálja. Bratislava: Mladé letá, 1966.

VANSOVÁ, Terézia: Marya Konopnická. O literárnej tvorbe na jej 25. ročné spisovatel'ské jubileum. Dennica, 1902, č. 11, s. $234-237$.

VANSOVÁ, Terézia: [osobná korešpondencia]. Nedatované. Dostupné v: LA SNK 230 B 21.

VANSOVÁ, Terézia: [osobná korešpondencia]. Nedatované. Dostupné v: LA SNK: 198 AB 4.

VANSOVÁ, Terézia: [osobná korešpondencia]. Nedatované. Dostupné v: LA SNK 198 X 16.

VANSOVÁ, Terézia: [osobná korešpondencia]. [1890-1-13]. Dostupné v: LA SNK 49 EE 31.

VANSOVÁ, Terézia: [osobná korešpondencia]. [1897-9-15]. Dostupné v: LA SNK 41 TTT 55.

VANSOVÁ, Terézia: [osobná korešpondencia [1926-3-31]. Dostupné v: LA SNK 150 I 8.

VANSOVÁ, Terézia: [osobná korešpondencia]. [1927-9-21]. Dostupné v: LA SNK 41 CC 33.

VANSOVÁ, Terézia: Pani Georgiadesová na cestách. Veselý cestopis do Prahy na národopisnú výstavu. Praha: Mazáčova slovenská knižnica, 1930.

VANSOVÁ, Terézia: Predmluva. In: NĚMCOVÁ, Božena: Babička. Zlatý fond denníka SME. [online]. [2016-10-4]. Dostupné na: http://zlatyfond.sme.sk/dielo/1830/Nemcova_Babicka.

VANSOVÁ, Terézia: [rukopis článku]. Nedatované. Dostupné v: LA SNK 198 AB 19.

VANSOVÁ, Terézia: [rukopis článku]. Dostupné v: LA SNK 198 AB 19

VANSOVÁ, Terézia: Sirota Podhradských. [online]. Dostupné na: http://zlatyfond.sme.sk/dielo/293/Vansova_Sirota-Podhradskych/1.

VANSOVÁ, Terézia: Slovenka doma i na cestách. Bratislava: Aspekt, 2011.

VANSOVÁ, Terézia: Viola Podhradská: román dívky. Bratislava: Mladé letá, 1972.

VANSOVÁ, Terézia: $Z$ rovín dolnozemských. Dennica 9, 1907, s. 156 - 159, 183 - 186, 228 - 230 , 288 - 291, 352 - 355, $396-400$.

VESELÝ, Adolf: Jubileum Terezie Vansové. Národní listy 77, 1937, č. 107, s. 15.

WEBER, Nora: Feminism, Patriarchy, Nationalism, and Women in Fin-De-Siecle Slovakia. Nationalities Papers, vol 25, n. 1. 1997, s. 35 - 65.

ZAVRTANIK, Maša: Fakti v literarnih delih Terezie Vansove kot vir pri spoznavanju načina življenja ljudi. Sofia: Nacionalni slavistični četenija, 2010, s. 577 - 582.

ZVRTANIK, Maša: Semiotizacija potopisa Terézie Vansove. In: URKOM, Aleksander (ed.): Fiatal Szlavisták Budapesti Nemzetközi Konferenciája I. Budapest: Eötvös Loránd Tudományegyetem, 
2012, s. 120 - 122. [online]. [cit. 19.03.2017]. Dostupné na: http://szlavintezet.elte.hu/szlavanyagok/youngslavist/1st\%20Conference\%20for\%20Young\%20Slavists\%20in\%20Budapest.pdf. Ženský obzor. [osobná korešpondencia]. [1923-12-28]. Dostupné v: LA SNK 41 JJ 7.

\section{Mgr. Eliška Gunišová}

Ústav slavistiky

Filozofická fakulta, Masarykova univerzita

Arna Nováka 1, 60200 Brno, Česká republika

egunisova@gmail.com 
